\title{
顎・ロ腔領域の外傷に関する臨床統計的観察
}

\author{
秋月弘道・吉田広 - 月岡克 郎・森紀美江 \\ 岡田隆・道健一
}

\section{Clinical and statistical investigation of injuries in oral and maxillofacial region}

\author{
Hiromichi AKızuki - Hiroshi Yoshida - Katurou Tukıoka \\ Kimie Mori - Takashi OKadA - Ken-ichi MichI
}

\begin{abstract}
This report analyzes the maxillofacial injuries of 521 patients treated at First Department of Oral and Maxillofacial Surgery, Showa University Dental Hospital in 1977 1985. The injuries were classified into four groups, depending on severity: Group 1, maxillary, mandibular and maler fracture; Group 2, tooth injury; Group 3, injury of oral soft tissue; Group 4, decubital ulcer of oral soft tissue. Factors analyzed were number, sex, patient age, and cause, location and treatment of the injury. Tooth injuries (Group 2) were the largest with $45.3 \%$ of the patients, while Group 1 was $24.4 \%$; Group 4, $15.6 \%$; and Group 3, $14.8 \%$. The male/female ratio indicated much more common fracture (Group 1) and tooth injury (Group 2) in male, while female had slightly higher occurrence of oral soft tissue injury (Group 3) and decubital ulcer (Group 4). Automobile accidents were the main cause of injuries in Group 1, falls in Group 2 and 3, prosthesis in Group 4. Just over ninety percent of fractures (Group 1) were of the mandible, and just over two-thirds of tooth injuries $(67.8 \%)$ were in the maxillary incisal region. Soft tissue injuries (Group 3) occurred mainly in the lip (35.1\%) and gingiva (17.5\%). Decubital ulcers (Group 4) were found in gingiva (48.1\%), tongue $(27.2 \%)$ and buccal mucosa $(12.3 \%)$. Most fracture patients were successfully treated by closed reduction and about sixteen percent of patients were treated by open reduction. Fifty-six percent of tooth injuries (Group 2) were luxated teeth, most of which were treated by repositioning and fixation.
\end{abstract}

Key words: oral and maxillofacial region, injury, statistical investigation

緒言

顎・ロ腔領域の外傷は原因となった外力の程 度, 種 類, 患者の年齢, 性別などによって受傷状態に特徵をも つことが考えられるが, 従来の臨床統計的観察において

昭和大学檤学部第 1 口腔外科学教室

（主任：道 健一教授）

First Depertment of Oral and Maxillofacial Surgery, School of Dentistry, Showa University (Chief: Prof. Ken-ichi Michi)

受付日: 昭和 62 年 2 月 2 日
は，骨損傷のみについての報告が多く1 11)，柬の損傷お よび軟部損伤についての報告あるいはこれらを含めた外 傷全体についての総合的な報告は少ない12,13)。われわれ は顎・ 口腔領域の䋶骨・煩骨骨折, 歯の損傷, 軟部損 傷,および慢性機械的刺激による褯㓣性溃瘍を含めた 521 症例の外傷患者を臨床統計的に検討したので報告す る.

\section{対象および検索方法}

検索対象は昭和 52 年 7 月〜昭和 60 年 6 月の 8 年間に当 科を受診した患者 12,994 名のらちの顎・腔領域の外傷 
表 1 症 例 数

\begin{tabular}{|c|c|c|c|c|c|c|c|}
\hline 年 度 & 1 群 & 2 群 & 3 群 & 4 群 & 総数 & $\begin{array}{l}\text { 外来総 } \\
\text { 患者数 }\end{array}$ & $\begin{array}{l}\text { 外来総 } \\
\text { 患者数 } \\
\text { に占め } \\
\text { る敖合 } \\
\end{array}$ \\
\hline 52 ( $7 \sim 12$ 月) & 0 & 2 & 2 & 2 & 6 & 506 & $1.2(\%)$ \\
\hline 53 & 14 & 25 & 2 & 8 & 49 & 1,137 & 4.3 \\
\hline 54 & 15 & 14 & 11 & 6 & 46 & 1,343 & 3.4 \\
\hline 55 & 15 & 17 & 3 & 4 & 39 & 1,385 & 2.8 \\
\hline 56 & 14 & 17 & 11 & 17 & 59 & 1,414 & 4. 2 \\
\hline 57 & 19 & 47 & 12 & 12 & 90 & 1,837 & 4.9 \\
\hline 58 & 14 & 39 & 13 & 17 & 83 & 1,995 & 4. 2 \\
\hline 59 & 22 & 51 & 16 & 9 & 98 & 2,069 & 4. 7 \\
\hline 60 (1〜 6月 $)$ & 14 & 24 & 7 & 6 & 51 & 1,308 & 3.9 \\
\hline 計 & 127 & 236 & 77 & 81 & 521 & 12,994 & 4.0 \\
\hline$\%$ & 24.4 & 15. & 8 & 5.6 & 100.0 & & \\
\hline
\end{tabular}

患者 521 症例であり, これらを受傷状態により次の 4 群 に分類した。

1） 1 群：上顎骨折（顔面中央 $1 / 3$ ), 下顎骨骨折, および煩骨弓骨折の単独あるいは重複骨折の症例（歯の 損傷, 軟部組織損傷を合併する症例も含み, 歯槽突起骨 折は除外する.)

2） 2 群: 歯の損傷の症例（歯槽突起骨折および軟部 損傷を合併する症例孔含む)

3） 3 群: 軟部損傷のみの症例（褯創性潰瘍症例は含 まない)

4） 4 群：口腔領域の褯創性潰瘍の症例

これら 4 群の頻度, 年齢, 性別, 受賃原因, 受傷部 位，および治療法について検討した。
結

果

\section{1. 頻 度}

当科外来患者総数に対する顋・口腔領域の外傷患者の 頻度は昭和 52 年度の開院当初を除いてほぼ 3 〜 5 であ った．各群別にみると 2 群が 236 例 (45.3\%) で最も多 く，ついで 1 群 127 例 (24.4\%)，4 群81例 (15.6\%)， 3 群77例 (14.8\%) の順であった. 年次別にみても各群 別の割合はほぼ同様の傾向であった（表1）.

\section{2. 性, 年齢別分布}

男女比をみると，1群では 5.0:1，2 群では 2.5:1 と圧倒的に男性に多かったが， 3 群では 0.9:1，4 群 では0.7:1と逆に女性に多い傾向がみられた。年齢別分 布をみると，1群では 10２0 歳代が全体の 64.6\%を占 め，20歳代にピークがみられたが， 2 群では10歳未満の ものが $50.8 \%$ を占めており，增齢とともに暫時減少する 傾向がみられた。 3 群でも 10 歳未満が $49.4 \%$ と最も多 く，2群とほぼ同様の傾向であった４４群では50歳代以 上が72.8\%を占め，高秢者に多くみられた（表 2 ）.

\section{3. 受傷原因別分類}

1 群では交通事故50例 (39.4\%), 眨打 21 例(16.5\%), スポーッ20例 $(15.7 \%)$, 転倒18例 $(14.2 \%) ， 2$ 群では 転倒106例 $(44.9 \%)$, 交通事故34例 $(14.4 \%)$ ， スポー ッ30例 $(12.7 \%), 3$ 群では転倒23例 $(29.9 \%)$, 転落 8 例 $(10.4 \%)$, 衝突 7 例 $(9.1 \%)$ の順であり, 各群の受 傷原因に相違がみられたが，全体としては転倒(33.4\%) が最も多く，次いで交通事故 $(20.5 \%)$ ，スポーツ(12.3 \%)，転落（10.0\%）の順であった（表３）．4群におい ては，補経物が原因になったものが 58 例 $(71.6 \%)$ ，歯 の鋭縁によるもの19例（23.5\%）であり食物を粘膜で直 接咀嚼していたために生じた外傷が 2 例みられた(表4).

表 2 性・年路別分布

\begin{tabular}{|c|c|c|c|c|c|c|c|c|c|c|c|c|c|c|c|}
\hline & \multicolumn{3}{|c|}{1} & \multicolumn{3}{|c|}{2 群 } & \multicolumn{3}{|r|}{ 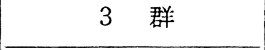 } & \multicolumn{3}{|r|}{ By } & \multicolumn{2}{|c|}{ 合 計 } & \multirow[b]{2}{*}{ 計 $(\%)$} \\
\hline & 男性 & 女性 & 計 $(\%)$ & 男性 & 女性 & 計 $(\%)$ & 男性 & 女性 & 計 $(\%)$ & 男性 & 女性 & 計 $(\%)$ & 男性 & 女性 & \\
\hline $0 \sim 9$ & 3 & 1 & $4(3.0)$ & 88 & 32 & $120(50.8)$ & 19 & 19 & $38(49.4)$ & 0 & 2 & $2(2.5)$ & 110 & 54 & $164(31.5)$ \\
\hline $10 \sim 19$ & 33 & 5 & $38(30.0)$ & 35 & 13 & $48(20.3)$ & 5 & 1 & $6(7.8)$ & 1 & 0 & $1(1.2)$ & 74 & 19 & $93(17.9)$ \\
\hline $20 \sim 29$ & 35 & 9 & $44(34.6)$ & 27 & 8 & $35(14.8)$ & 4 & 8 & $12(15.6)$ & 2 & 1 & $3(3.7)$ & 68 & 26 & $94(18.0)$ \\
\hline $30 \sim 39$ & 18 & 0 & $18(14.2)$ & 9 & 7 & $16(6.8)$ & 2 & 6 & $8(10.4)$ & 2 & 5 & $7(8.6)$ & 31 & 18 & $49(9.4)$ \\
\hline $40 \sim 49$ & 8 & 2 & $10(7.9)$ & 3 & 4 & $7(3.0)$ & 4 & 1 & $5(6.5)$ & 4 & 5 & $9(11.1)$ & 19 & 12 & $31(6.0)$ \\
\hline $50 \sim 59$ & 6 & 2 & $8(6.3)$ & 5 & 3 & $8(3.4)$ & 1 & 5 & $6(7.8)$ & 7 & 11 & $18(22.2)$ & 19 & 21 & $40(7.7)$ \\
\hline $60 \sim 69$ & 2 & 1 & $3(2.4)$ & 2 & 0 & $2(0.8)$ & 1 & 0 & $1(1.3)$ & 3 & 10 & $13(16.0)$ & 8 & 11 & $19(3.6)$ \\
\hline $70 \sim 79$ & 0 & 0 & $0(0.0)$ & 0 & 0 & $0(0.0)$ & 0 & 1 & $1(1.3)$ & 10 & 9 & $19(23.5)$ & 10 & 10 & $20(3.8)$ \\
\hline $80 \sim 89$ & 1 & 1 & $2(1.6)$ & 0 & 0 & $0(0.0)$ & 0 & 0 & $0(0.0)$ & 4 & 5 & $9(11.1)$ & 5 & 6 & $11(2.1)$ \\
\hline 計 & 106 & 21 & $127(100.0)$ & 169 & 67 & $236(100.0)$ & 36 & 41 & $77(100.0)$ & 38 & 48 & $81(100.0)$ & 344 & 177 & $521(100.0)$ \\
\hline 男：女 & & & & & & $5: 1$ & & & & & & 1 & & & $: 1$ \\
\hline
\end{tabular}


表 3 受管原因 $(\%)$

\begin{tabular}{|c|c|c|c|c|}
\hline & 群 & 群 & 群 & 計 \\
\hline 倒 & $18(14.2)$ & $106(44.9)$ & $23(29.9)$ & \\
\hline c通事故 & $50(39.4)$ & $34(14.4)$ & $6(7.8)$ & $90(20.5)$ \\
\hline スポーッ & $20(15.7)$ & $30(12.7)$ & $4(5.2)$ & $54(12.3)$ \\
\hline 落 & $11(8.7)$ & $25(10.6)$ & $8(10.4)$ & $44(10.0)$ \\
\hline 突 & $6(4.7)$ & $22(9.3)$ & $7(9.1)$ & $35(8.0)$ \\
\hline 打 & $21(16.5)$ & $12(5.2)$ & $2(2.6)$ & $35(8.0)$ \\
\hline & $1(0.8)$ & $3(1.3)$ & $0(0$ & $.0)$ \\
\hline その他 & $0(0)$ & $4(1.7)$ & $27(35.1)$ & $31(7.0)$ \\
\hline & $(100.0$ & (1) & $r(100.0)$ & 100.0 \\
\hline
\end{tabular}

表 4 褯創性潰瘳の受賃原因（\%)

\begin{tabular}{|c|c|c|c|c|}
\hline \multirow{2}{*}{\multicolumn{2}{|c|}{ 補綴物 }} & 義 荬 & $53(65.4)$ & \multirow{2}{*}{$58(71.6)$} \\
\hline & & その他 & $5(6.2)$ & \\
\hline \multicolumn{3}{|c|}{ 菌 } & & $19(23.5)$ \\
\hline 食 & \multicolumn{2}{|l|}{ 物 } & & $2(2.5)$ \\
\hline & \multicolumn{2}{|l|}{ 明 } & & $2(2.4)$ \\
\hline \multicolumn{3}{|c|}{ 計 } & & $81(100.0)$ \\
\hline
\end{tabular}

表 5 骨折部位 $(\%)$

\begin{tabular}{|c|c|}
\hline 部位 & 症例数 \\
\hline 下顎骨のみ & $105(82.7)$ \\
\hline 下顎骨十上顎 & $5(3.9)$ \\
\hline 下顎骨＋上顎＋煩骨弓 & $4(3.1)$ \\
\hline 下顎骨＋煩骨弓 & $1(0.8)$ \\
\hline 上顎 & $6(4.7)$ \\
\hline 上顎＋煩骨弓 & $3(2.4)$ \\
\hline 頓 骨 & $3(2.4)$ \\
\hline 計 & $127(100.0)$ \\
\hline
\end{tabular}

表 6 下顎骨骨折の部位 (\%)

\begin{tabular}{|c|c|c|c|}
\hline & 単線骨折 & 複線骨折 & 合 計 \\
\hline 関節突起部 & $16(25.8)$ & $31(29.2)$ & $47(28.0)$ \\
\hline 前茵部 & $10(16.1)$ & $33(31.1)$ & $43(26.0)$ \\
\hline 臼粎部 & $21(33.9)$ & $17(16.0)$ & $38(22.6)$ \\
\hline 顎角部 & $14(22.6)$ & $16(15.1)$ & $30(17.9)$ \\
\hline 下顎枝部 & $1(1.6)$ & $7(6.7)$ & $8(4.8)$ \\
\hline 筋突起部 & $0 \quad(0)$ & $2(1.9)$ & $2(1.2)$ \\
\hline 計 & $62(100.0)$ & $106(100.0)$ & $188(100.0)$ \\
\hline
\end{tabular}

表 7 蒾の外偟の受侱部位（\%)

\begin{tabular}{|c|c|c|c|c|c|}
\hline & 中切蔽 & 側切幽 & 犬 茀 & 白㳡 & 計 \\
\hline 上 顎 & $287(48.8)$ & $98(16.7)$ & $14(2.4)$ & $5(0.9)$ & $404(68.4)$ \\
\hline 下 顎 & $88(15.8)$ & $61(10.4)$ & $27(4.6)$ & $8(1.4)$ & $184(31.6)$ \\
\hline 計 & $375(63.8)$ & $159(27.0)$ & $41(7.0)$ & $13(2.2)$ & $588(100.0)$ \\
\hline
\end{tabular}

\section{4. 受傷部位別分類}

1 群では下顎骨骨折単独の症例が 105 例 (82.7\%) で あり，下顎骨骨折に上顎骨折，頓骨弓骨折を合併したも のを含めると115例 (90.5\%)であった。顎骨折単独の 症例は 6 例 $(4.7 \%)$, 頓骨弓骨折単独の症例は 3 例 $(2.4$ \%)であった(表 5 )。症例数の多い下龥骨骨折について みると単線骨折は62例，複線骨折は65例であり，骨折部 位を単線, 複線骨折の合計の骨折線数でみると関節突起 部 47 線 $(28.0 \%)$, 前歯部 43 線 $(26.0 \%)$, 臼歯部 38 線 (22.6\%), 㴿角部30線 (17.9\%) の順であった（表 6). 2 群では上罘中切歯 287 歯 (48.8\%), 上靧側切歯 98 歯 (16.7\%), 下顎中切歯88歯 $(15.8 \%)$, 下頡側切歯 61 歯 (10.4\%)で上下顎中切歯，および側切䨑が全体の $90.8 \%$ を占めていた（表 7 ）。3 群では上下口唇が 28 例（35.1 $\%)$, 歯肉14例 $(17.5 \%)$, 舌10例 $(12.5 \%)$, 頓粘膜 10 例(12.5\%)，上唇小带 8 例（10.0\%）の順であった（表
8 ). 4 群では歯肉39例 (48.1\%), 舌22例 $(27.2 \%)$, 頓 粘膜10例 (12.3\%) の順であった（表 9).

\section{5. 治療法}

1 群の 127 例の中で新鮮骨折は107例 (84.2\%), 陳旧 性骨折は20例 (15.8\%) であった。これらに対する治療 としては非観血的整復術が68例 $(53.5 \%)$, 観血的整復 術が21例（16.5\%）に対して行われた。そのらち観血的 整復術 21 症例のうちわ忛，陳旧性骨折症例のうちの 13 例, 乳歯列症例 4 例, 頓骨弓骨折 1 例, 成人の新鮮骨折 に対して金属プレートを使用した症例 3 例であった。関 節突起部骨折に対しては, 陳旧性で開口障害を併発した 1 例に対して観血的な靧関節授動術が行われた以外は, すべて保存的処置が行われた，その他孩片の偏位の小 さい症例はチンキャップおよび歯の削合, 拔歯などの処 置により治療された（表 10）。顎間固定期間については 観血的整復術を行ったものでは平均 43.4 日（8～69日） 
表 8 軟組織外傷の受傷部位（\%)

\begin{tabular}{|c|c|}
\hline 口 唇 & $28(35.1)$ \\
\hline 歯 肉 & $14(17.5)$ \\
\hline 舌 & $10(12.5)$ \\
\hline 頓 & $10(12.5)$ \\
\hline 上唇小帯 & $8(10.0)$ \\
\hline 蓋 & $5(6.3)$ \\
\hline 口 底 & $1(1.3)$ \\
\hline 顔面皮膚 & $4(5.0)$ \\
\hline 計 & $80(100.0)$ \\
\hline
\end{tabular}

表 9 裖創性潰瘍の受伤部位（\%)

\begin{tabular}{|c|c|c|}
\hline 檤 & 肉 & $39(48.1)$ \\
\hline \multicolumn{2}{|c|}{ 舌 } & $22(27.2)$ \\
\hline \multicolumn{2}{|c|}{ 頓 } & $10(12.3)$ \\
\hline 口 & 蓋 & $5(6.2)$ \\
\hline 口 & 底 & $4(4.9)$ \\
\hline 口 & 唇 & $1(1.2)$ \\
\hline \multicolumn{2}{|c|}{ 計 } & $81(100.0)$ \\
\hline
\end{tabular}

表 10 骨折治療

\begin{tabular}{|c|c|}
\hline 非観血的整復術 & $68(53.5)$ \\
\hline 観血的整復術 & $21(16.5)$ \\
\hline チンキャップのみ & $10(7.9)$ \\
\hline 開口練習 & $5(3.9)$ \\
\hline 義药・歯の処置 & $5(3.9)$ \\
\hline 顎関節授動術 & $1(0.8)$ \\
\hline 転 科 & $11(8.7)$ \\
\hline 経過観察 & $6(4.7)$ \\
\hline 計 & $127(100.0)$ \\
\hline
\end{tabular}

であったがこのなかで金属プレートを使用した症例では 13.0日（8～30日）であった。非観血的整復術では平均 31.7日（7～66日）で，これらの5ち関節突起部の骨折 に対して非観血的整復が行われた症例では平均 15.1 日 （7〜43日）であった（表 11）．2 群では完全脱臼した乳 歯 7 歯，永久歯25崡に対して再植・固定が行われた。不 完全脱臼では乳歯121歯中46歯 (38.0\%), 永久歯 283 歯 中 197 歯 (69.6\%) が整復・固定された。また粷根・歯 冠破折歯では乳柬12歯（92.3\%）が抜歯され，永久歯87 歯中58歯 (66.7\%) に保存処置がなされた３群では主 に創部の洗浄, デブリードマン, 艂合が行われた。 4 群 では原因となった補経物の調整, 樯の削合, 抜歯, およ び創部への軟高の塗布が行われ，治疮までの期間につい てみると経過の明らかな51例中 28 例 $(54.9 \%)$ が 2 週間 以内に治疮している (表12).
表 11 顎間固定期間（日）

\begin{tabular}{l|l|c|c}
\hline \multicolumn{2}{c|}{ 術 } & 平均固定期間 \\
\hline \multirow{2}{*}{ 観血的整復術 } & 金属プレート使用 & 13.0 & \multirow{2}{*}{43.4} \\
\cline { 2 - 4 } & その他 & 49.1 & 4 \\
\hline \multirow{2}{*}{ 非観血的整復術 } & 下顎関節突起部 & 15.1 \\
\cline { 2 - 4 } & 下顎関節突起部以外 & 33.4 \\
\hline
\end{tabular}

表 12 褯創性溃痬の治痛までの期間（\%)

\begin{tabular}{c|c}
\hline 期 & 間 \\
\hline 1 週間未満 & $17(33.3)$ \\
$1 \sim 2$ 週間 & $11(21.6)$ \\
$2 \sim 3$ 週間 & $6(11.8)$ \\
$3 \sim 4$ 週間 & $5(9.8)$ \\
4 週以上 & $12(23.5)$ \\
\hline 計 & $51(100.0)$ \\
\hline
\end{tabular}

考察

従来, 面・口腔領域の外傷は, 交通事情や社会環境の 変化などにより年々増加の傾向がみられるといわれてい たが，昭和50年頃から增加の傾向はみられず横這いの状 態になっているとの報告が多い8 11)，われわれの集計で も昭和53年〜昭和 60 年の総患者数に占める外傷患者の割 合は $4 \%$ 前後でとくに增加の傾向はみられなかった。口 腔領域の外傷は受傷部位から骨損傷，歯の損傷および軟 部損傷に分類されている ${ }^{16)}$ ，これらのらち骨損傷につい ては臨床統計的な報告が数多くみられるが，それ以外の 荬の損傷, 軟部損傷についての報告は少ない12 15)ため, それらを含めた外賃全体についての臨床病態はいまだ不 明な点が多い，そこでわれわれは歯の損傷，軟部損傷お よび慢性外傷による褯創性潰瘍を含めた外傷について臨 床統計的な検討を加えることによりその病態を臨床的に 明らかにすることを試みた。なお，今回の統計では外傷 に対する処置内容によって症例を分類し，歯槽骨骨折は 粜の外傷に含めることとした，外価症例の性別について は福井 ${ }^{3}$ らが，顎骨骨折では12.5:1，歯槽骨損傷では 6. $2: 1$ で両者を比較すると，歯槽骨損傷に比べて顎骨 骨折の方が男性に多いと報告しており，われわれの結果 と同様であった．しかし，3群，4群についての報告は ほとんどみられず，小児の外傷について渡辺 ${ }^{12}$ ら，三宮 ら ${ }^{13)}$ の報告があるにすぎない.今回の結果から各群の性 別を比較すると受伤の程度が重篤な 1 群，2群に男性の 占める割合が多く，3 群，4群ではやや女性に多いとい 
ら結果であった。受傷年齡では従来の報告 ${ }^{111)}$ と同 様 に, 1 群は10〜20歳代, 2 群, 3 群は10歳未満に多かっ た. その理由としては幼児では歩行が不安定なため, 転 倒, 衝突の機会が多いが, 体重が軽く身体が柔軟である ためにその衝撃は比較的小さいからであろらと考えられ た． 4 群で50〜70歳代が多い理由としては高齢者では補 経物を使用する頻度が高いためと思われた。

1 群， 2 群および 3 群の急性外傷の原因についてみる と，1群では交通事故，殴打， スポーツ，2 群では転 倒, 交通事故, スポーツ, 3 群では転倒, 転落, 衝突の 順であった。このように各群の間で原因に差がみられた 理由は, 交通事故は受傷時の衝揧力が大きいため, 1 群 の中に占める割合が高くなるが, 転倒では交通事故と比 較すれば衝撃力が小さいため顎骨骨折にまでいたらない 2 群, 3 群に占める割合が高くなるものと思われた.

受傷部位については安河内ら ${ }^{15}$ が，買骨骨折の上下顎 比は，1.10で下顎に多いが，歯槽骨骨折と歯牙外傷で は，それぞれ4.9:1，8.2:1と上䪽に多く，しかも前歯 部に集中していたと報告しており，われわれと同様の結 果であった。1群で上䫟に比較して下顎骨に骨折が多い 理由として下顎の位置が外力を受けやすいこと, 解剖学 的形態から上顎に比較して下顎の方が骨体骨折を起こし やすいこと，および上顎骨折の場合には脳損傷や眼損傷 を伴らことが多いために，他科受診例が多いことなどが あげられる。これに対し 2 群の歯の外部が上顎に多い理 由としては，歯列弓では上顎が下顎を被らように位置し ているため, 受傢の機会が多いものと考えられた。 3 群 では上下口唇, 前歯部歯肉, 舌前方部, および口角付近 の頓粘膜部の損傷が大部分であったが，これは粘膜が外 界に露出し, 形態的にも複雑な口裂付近が最も外力に対 して抵抗力が弱いためと思われた。 また，口蓋部の損傷 についてみると，われわれの集計では， 5 例中 4 例が 3 歳未満の幼児での異物刺入によるものであった。渡辺 $5^{12)}$ も15歳以下の外傷患者においては, 口蓋部損傷の 83\%が 3 歳以下の幼児であったと報告している。この理 由としては幼児はよちよち歩きで歩行が不安定で，かつ 物を口にくわえて遊ぶことが多いためと考えられ，口蓋 部損傷は幼罗に特有の外傷と思われた４４群では補経物 により損傷を受けやすい歯肉や，運動量が多く歯の鋭縁 や不良補綴物により損傷を受けやすい舌に受傷したもの が多かった。

治療法は前述のとおりであるが, 非観血的整復術後の 顎間固定期間については従来， $4 \sim 7$ 週とい5報告 ${ }^{1 \sim 11)}$ が多かったが，われわれの集計では平均33.4日（4.8週） であり，やや短い傾向であった。とくに若年者で骨折片 の変位の少ない症例では 7 ～10日の固定で良好な結果を 得ており偽関節, 咬合不全などの異常治癒経過を示した ものはなかった。この結果から症例によっては観血的な 固定術を行わなくても短期間の枵頁間固定だけで良好な治
療効果が得られるものと思われた。 また，関節突起部の 骨折に対して非観血的処置が行われた症例で，経過中に 軽度の開口障害や咬合不全がみられたものもあったが, これらは暫時改善され良好な結果が得られた。このこと は, 従来からいわれているように関節突起部の骨折の治 療は非観血的な保存的処置により良好な結果が得られる といら報告17 19)を裏つけるものと思われた。

歯の外傷においては外傷を受けた歯は可及的保存的に 処置されるべきであるといわれており，従来は金属線結 禁や即時重合レジンにより固定されることが多かったが 近年は接着性レジンの開発により矯正用ブラケットや口 腔外科用ブラケットによる整復固定 ${ }^{20)}$ が多く行われるよ らになった。とくに乳雨において短時間の操作で適切な 固定が可能になったことから再植, 整復固定の適応範囲 が払がってきた，完全脱臼歯の再植後の成績についてみ ると, 調査可能であったのは19歯であったが，2か月〜 2 年の経過観察で良好な経過を得たものは15齿(78.9\%) であり,このうち 8 歯は受傷後 2 時間以内に再植された ものであった。予後不良のため再植後に抜歯された 4 歯 は再植されるまでの時間が長く，16時間〜72時間の後に 再植されたものであることから，従来からいわれてい る21)ように再植の場合には再植されるまでの時間が予後 を左右する最も大きな要因となっていると思われた

口腔軟組織の創傷治瘜は，一般に良好であるといわれ ている12)が，われわれの症例ではとくに重篤な合併症の みられたものはなかった。慢性刺激による褯創性潰瘍 は，一般に原因を除去することにより数日で治瘉すると いわれているが，これに関する臨床統計的な報告はみら れていない.われわれの集計では39. $2 \%$ が 1 週間以内に 治嘴したが，4週間以上の経過をとったものもみられ た。治㾚までの期間が長かった症例は義歯不適合による ものが大多数であり，特に長期間を要したものは義歯の 調整に手間取ったものが多かった。

\section{結}

語

われわれは顎・口腔領域の外傷患者 521 症例を 1 群 : 買骨・頓骨骨折症例， 2 群：雪の損傷症例， 3 群：軟部 損傷症例, および 4 群 : 慢性機械的刺激による褿創性潰 瘍症例の 4 群に分類し, 各群の頻度, 性別, 年齡, 受傷 原因，受傷部位，および治療法について臨床統計的に検 討し次の結果を得た。

1）外来患者総数の占める外傷患者の割合は，各年と もほぼ～5\%で年度別に大きな変化はみられなかっ た。

2）性別では， 1 群，2群は圧倒的に男性が多く，逆 に 3 群，4 群ではやや女性に多かった。年齢では 1 群は 10～20 歳代が全体の $64.6 \% ， 2$ 群は 10 歳未满のものが $50.8 \% ， 3$ 群は10歳未満が $49.4 \% ， 4$ 群では50歳代以上 
が71. 8\%を占めていた.

3) 原因別に2ると 1 群では交通事故 (39.4\%), 2 群では転倒 (44.9\%), 3 群では転倒 $(29.9 \%), 4$ 群で は不良補緅物 (71.6\%) が多く各群の原因に特徵がみら れた。

4）受傷部位については，1群では下靧骨単独および 下靧骨に煩骨弓，上顎の骨折を合併したものが $90.5 \%$ を 占め, 下罘骨骨折の好発部位は関節突起部 $28.0 \%$, 前米 部 $26.0 \%$ ， 臼歯部の $22.6 \%$ であった。 2 群では全体の $90.8 \%$ 卡下㴿中切歯拉よび側切歯であった。 3 群では 上下口唇部 $35.1 \%$ ，歯肉部 $17.5 \% ， 4$ 群では歯肉部 48. $1 \%$, 舌 $27.2 \%$ であった.

5）治療法としては，1 群では非観血的整復術が68例 (53.5\%)，観血的整復術が21例（16.5\%）に行われた. 靧間固定期間は観血的整復術施行例では平均 43.4日で, 非観血的整復術では平均31.7日であり, 関節突起部骨折 の非観血的整復が行われた症例では平均15.5日であった が, この治療法による異常治瘾症例は認められなかっ た. 2 群では完全脱曰した乳雨 7 函(26.9\%), 永久歯 25 歯 (43.1\%) に対して再植・固定が行われ，不完全脱且 の乳歯121歯中 46 歯 (38.0\%), 永久歯283歯中197歯 $(69.6$ \%) に整復・固定が行われた.

本論文の要旨は第 38 回日本口腔科学会総会 (昭和59年 5 月18日 東京）に批いて発表した。

\section{引用文 献}

1）古屋英毅，金井靖夫，他：最近13年間に打ける 本学病院を訪九た䫇骨骨折患者の統計的微察. 日口外誌 16：18-24 1970.

2）金城 孝, 山城正宏, 他: 過去 7 年間の当科飞 怙计万顎顔面骨骨折の臨床統計的観察。 日外 誌 $28: 424-4291982$.

3）福井勝男, 中田実, 他: 昭和 34 年度以降に抽 ける顎骨骨折の統計的観察。 日只外誌 13 : 203-208 1967.

4) 野間弘康, 河内 博, 他: 顎顔面骨骨折の統計 的観察. 日外誌 18: 450-455 1972.

5）乙貫典子, 朝倉昭人, 他：独協医科大学口腔外 科に打ける過去 6 年間の䫇骨骨折の臨床統計的 観察。 日外誌 28: 1551-1559 1982.

6）竹之下康治, 納富一幸, 他：顎骨を中心とする 颜面骨骨折様相の推移。口科誌 31: 407-418
1982.

7) 小浜源郁, 古田 勲：下顎骨骨折 317 症例に関 する臨床的検討，特に骨折線上の宷牙につい て。 日外誌 23: 237-242 1977.

8）鉿木和彦, 三宅久実男, 他: 過去 12 年間当教室 に扣ける顎顔面骨骨折の臨床統計的観察. 日口 外誌 24: 1084-1091 1978.

9）西原茂昭，長谷川幸司，他：過去15年間の当教 室に扣ける顎骨骨折の臨床統計的観察。日口外 誌 26: 726-733 1980.

10）藤岡幸雄, 中山栄雄, 他: 過去 3 年間に扣ける 顎骨骨折患者の動向について。 口科誌 18:2762841969.

11）川村 仁，橋本 涉，他：外筀性顎顔面骨骨折 について その 1 臨床統計的観察. 日口外誌 23: 809-818 1977.

12）渡辺義男, 西嶋克巳, 他: 過去 10 年間のわが教 室に拈ける小児外賃の臨床統計的観察。小児歯 誌 6: 175-179 1968.

13）三宮恵子, 安藤智博, 他 : 過去 6 年間の当教室 に扣ける小先䫇顔面口腔外傷の臨床統計的観 察. 日口外誌 29: 674-678 1983.

14）吉岡敏雄, 岡光夫, 他: 新潟大学相科に扣け る買骨々体骨折扣よび米槽骨骨折の 4 年11か月 にわたる臨床的钼察。口科誌 10：361-368 1961.

15）安河内茂, 伊藤友已：過去 5 年間の顎・口腔 領域の外賃に関する臨床統計的䂓察。日口外誌 23: 825-829 1977.

16) 小野尊㓐：口腔外科学. 第 1 版, 金芳堂, 京都, 1982，99-131頁.

17）小林清司, 佐々木 勲, 他：下顎骨骨折に対す るミニプレートの使用経験. 日口外誌 31 : 1180-1184 1985.

18）增村典子, 高橋良夫, 他：下顎骨骨折の臨床統 計的検討微察ならびに顎関節突起骨折の予後に ついて。 日口外誌 28：2028-2035 1982.

19）久保四郎，村橋護，他：顎関節突起骨折 124 症例に関する噪床的統計, 特にその分類につい て。 日外誌 29：1794-1805 1983.

20）吉增秀實，鹿島健司，他：口腔外科用ブラヶッ トの開発一第 2 報 臨床応用について一 日ロ 外誌 31: 1153-1156 1985.

21) J.A. Hargreaves（稗田豐治訳）：外伤前俻の治 療. 第 1 版, 医读薬出版, 東京, 1983, 102105 真. 